Stephen F. Austin State University

SFA ScholarWorks

\title{
Using GIS-Based, Regional Extent Habitat Suitability Modeling to Identify Conservation Priority Areas: A Case Study of the Louisiana Black Bear in East Texas
}

\author{
Christopher E. Comer \\ Arthur Temple College of Forestry and Agriculture, Stephen F. Austin State University, Nacogdoches, \\ Texas 75962, comerce@sfasu.edu \\ I-Kuai Hung \\ Arthur Temple College of Forestry and Agriculture, Stephen F. Austin State University, hungi@sfasu.edu \\ Gary Calkins \\ Dan J. Kaminski \\ Nathan Garner
}

Follow this and additional works at: https://scholarworks.sfasu.edu/forestry

Part of the Forest Sciences Commons

Tell us how this article helped you.

\section{Repository Citation}

Comer, Christopher E.; Hung, I-Kuai; Calkins, Gary; Kaminski, Dan J.; and Garner, Nathan, "Using GIS-Based, Regional Extent Habitat Suitability Modeling to Identify Conservation Priority Areas: A Case Study of the Louisiana Black Bear in East Texas" (2013). Faculty Publications. 278.

https://scholarworks.sfasu.edu/forestry/278

This Article is brought to you for free and open access by the Forestry at SFA ScholarWorks. It has been accepted for inclusion in Faculty Publications by an authorized administrator of SFA ScholarWorks. For more information, please contact cdsscholarworks@sfasu.edu. 


\title{
Using GIS-Based, Regional Extent Habitat Suitability Modeling to Identify Conservation Priority Areas: A Case Study of the Louisiana Black Bear in East Texas
}

\author{
DAN J. KAMINSKI, ${ }^{\mathbf{1 , 2}}$ Arthur Temple College of Forestry and Agriculture, Stephen F. Austin State University, 419 E. College Street, Nacogdoches, \\ TX 75962, USA \\ CHRISTOPHER E. COMER, Arthur Temple College of Forestry and Agriculture, Stephen F. Austin State University, 419 E. College Street, \\ Nacogdoches, TX 75962, USA \\ NATHAN P. GARNER, Texas Parks and Wildlife Department, Region 3 Office, 11942 FM 848, Tyler, TX 75707, USA \\ I-KUAI HUNG, Arthur Temple College of Forestry and Agriculture, Stephen F. Austin State University, 419 E. College Street, Nacogdoches, TX \\ 75962, USA \\ GARY E. CALKINS, Texas Parks and Wildlife Department, District 6 Wildife Office, 289 CR 98, Jasper, TX 75951, USA
}

\begin{abstract}
State and federal recovery plans mandate that priority areas for future population expansion be identified within the historical range of the Louisiana black bear (Ursus americanus luteolus). Despite the presence of potentially suitable habitat in east Texas and expanding populations in adjacent states, quantitative estimates of regional habitat suitability do not exist. We developed a regional extent habitat suitability index (HSI) model in a geographic information system (GIS) to evaluate year-round habitat requirements for black bears in the $43,530-\mathrm{km}^{2}$ south black bear recovery zone in southeastern Texas. We measured hard and soft mast production, understory vegetation density, and tree den availability at 516 survey points in 38 habitat classes ( $82 \%$ of the total area in the south recovery zone). We developed geospatial models for summer food availability; fall food availability, diversity, and productivity; protection cover, tree den availability, distance to roads, and human development zones and calculated HSI scores per pixel in a continuous dataset. Habitat suitability scores ranged from 0.00 to 0.76 throughout southeastern Texas. Highly $(<1 \%)$ and moderately $(16 \%)$ suitable habitat existed in the region, although most area $(84 \%)$ was classified as marginal or unsuitable habitat. We identified 4 recovery units comprising $>20,700$ ha (mean $\mathrm{HSI}=0.5$ ) capable of sustaining viable black bear populations. These units ranged from 62,844 ha to 124,808 ha in size and suitable habitat pixels within units ranged from 0.58 to 0.60 in mean HSI scores. Recovery unit scores were comparable to those previously reported for occupied bear range in the southeastern United States and acreages of suitable habitat exceeded those estimated to support existing Louisiana black bear populations. (c) 2013 The Wildlife Society.
\end{abstract}

KEY WORDS conservation, east Texas, geographic information system (GIS), geospatial modeling, habitat suitability index (HSI), Louisiana black bear, priority areas, Ursus americanus luteolus.

The identification and delineation of priority areas for conservation is a fundamental issue for the effective application of conservation resources (Gerrard et al. 2001, Clevenger et al. 2002, Felix et al. 2004). For species that require large contiguous habitats or exist at relatively large spatial scales, a landscape approach is necessary for adequately identifying appropriate focal areas for conservation (Osborne et al. 2001, Linden et al. 2011). The availability of spatial analysis tools like geographic information systems (GIS) allows conservation managers to assess

Received: 12 November 2012; Accepted: 10 June 2013

Published: 19 September 2013

${ }^{1}$ E-mail: danjkaminski@yahoo.com

${ }^{2}$ Present address: 4222 38th Street, Des Moines, IA 50310 habitat availability and quality at a regional or landscape scale (Felix et al. 2004). In occupied areas, wildlife managers may estimate the suitability of used habitats using radio telemetry or observation data and develop models that extrapolate values to a regional scale (Danks and Klein 2002, O'Brien et al. 2005, Rubin et al. 2009). However, in the absence of the target species, identifying priority areas poses unique challenges for wildlife managers interested in using established modeling techniques for regional reintroduction and monitoring efforts (Didier and Porter 1999).

Since the early 1980s, habitat suitability index (HSI) models have been used to assess environmental impacts to wildlife populations, predict habitat suitability (i.e., the ability of a given habitat to support a given species) and use by wildlife populations, and facilitate management planning 
activities (U.S. Fish and Wildlife Service 1980, Allen 1983, Cook and Irwin 1985, Brooks and Temple 1990, van Manen and Pelton 1997, Gurnell et al. 2002). HSI models quantify habitat suitability based on known life requisites and habitat requirements for a given species. Habitat variables (e.g., food production or nest site availability) are evaluated on an index scale from 0 (unsuitable habitat) to 1 (optimum suitability). Traditional HSI models were designed to evaluate habitat based on the minimum area necessary for a species to reproduce and survive and to assign a mean suitability score to relatively large geographic extents (U.S. Fish and Wildlife Service 1980). However, with the development of GIS and advances in GIS software, computer hardware, and satellite technologies, sources of data such as remote satellite and aerial photographic imagery, land-cover models, and digital elevation models have allowed for the development of more detailed HSI models and their application to landscapescale restoration and management efforts (Didier and Porter 1999, McComb et al. 2002, Larson et al. 2003, Felix et al. 2004).

Because of the coarseness of most geospatial data, landscape-scale HSI models are well suited for habitat generalists and species with large spatial requirements (Clark et al. 1993, O'Brien et al. 2005). HSI models are commonly applied to American black bear (Ursus americanus) populations to estimate and predict habitat suitability (van Manen 1991, Tankersley 1996, Hersey et al. 2005). Because management decisions regarding bears are often made at the population level, multiple GIS-based, regional extent models have been developed to evaluate suitable habitats for black bears (van Manen and Pelton 1997, Bowman 1999, Mitchell et al. 2002, Larson et al. 2003). Considering the general habitat preferences of black bears, the substantial existing spatial data available regarding black bear habitat suitability, and the sizeable percent of historical range unoccupied by black bear species in North America (39\%; Laliberte and Ripple 2004), black bears provide an ideal example to which GIS tools may be applied to identify priority areas in the absence of a target species or site-specific habitat use data.

East Texas is located within the historical range of the state and federally threatened Louisiana black bear (Ursus americanus luteolus). Although once common throughout eastern Texas, the Louisiana black bear had become rare by the early twentieth century and was considered extirpated by the 1940s due to indiscriminant and unregulated hunting coupled with extensive clearing of bottomland hardwood forests for agriculture (Texas Parks and Wildlife Department 2005a). The current distribution of the Louisiana black bear is restricted to 3 populations in central and eastern Louisiana and western Mississippi, although recent data suggest that these populations are expanding (Black Bear Conservation Coalition, unpublished data). Factors restricting growth and expansion of the current population include habitat loss, fragmentation, and human-induced mortality (e.g., roadkill and illegal harvest). East Texas is believed to contain some of the largest tracts of forested habitat available to but currently unoccupied by black bears in the southeast (Wooding et al. 1996) and may contribute to the future recovery of the Louisiana black bear.

In 2009, we initiated a study designed to quantitatively assess the suitability of east Texas habitats for the Louisiana black bear. Our objective was to identify conservation priority areas across the landscape capable of sustaining viable populations within the historical range of the Louisiana black bear in east Texas. Because of the large spatial requirements of black bears, increasing numbers of confirmed reports of transient bears throughout east Texas, and the general lack of habitat information throughout the region, our goals were to 1 ) evaluate east Texas habitats at a regional scale using a statistically valid habitat survey, 2) develop a spatially explicit HSI model using previously established black bear HSI models and a statistically validated habitat field survey that could be used to evaluate year-round habitat requirements for Louisiana black bears in the absence of site-specific use data, and 3) determine whether large, contiguous areas of suitable habitats capable of sustaining viable black bear populations exist in east Texas.

\section{STUDY AREA}

We developed our HSI model for the 43,530- $\mathrm{km}^{2}$ south Louisiana black bear recovery zone (SRZ), which included 19 counties in east Texas (Fig. 1). The SRZ is 1 of 2 recovery zones within the historical distribution of the Louisiana black bear in east Texas and was delineated by the East Texas Black Bear Task Force to target habitat conservation programs and black bear restoration efforts in east and southeast Texas. The SRZ was located in the Pineywoods ecoregion of east Texas and consisted of rolling topography mostly dominated by closed or nearly closed canopy pine and pine-hardwood forests in the uplands and bottomland hardwood forest in the bottomlands. Elevations within the region ranged from $15 \mathrm{~m}$ to $150 \mathrm{~m}$ (Nixon 2000, Texas Parks and Wildlife Department 2005b). The climate was mesothermal and characterized by hot, humid summers and mild winters (Nixon 2000). The mean annual temperature in the region ranged from $8.4^{\circ} \mathrm{C}$ to $18.7^{\circ} \mathrm{C}$, whereas annual rainfall ranged from $89 \mathrm{~cm}$ to $152 \mathrm{~cm}$ (National Oceanic and Atmospheric Administration 2002a, 2002b).

In 2009, the Texas Parks and Wildlife Department released the Texas Vegetation Classification Project (Phase II; TVCP), geospatial habitat classification dataset, for the eastern portion of the state (Texas Natural Resource Information System, Austin, TX). The TVCP was derived from remote sensing of Landsat thematic mapper (TM) satellite imagery, aerial photo interpretation, digital soil surveys, digital elevation models, and ground-truthing surveys, and included 119 habitat classes at 10-m resolution. According to the TVCP, 38\% of the land cover in the SRZ was in pine forest, $26 \%$ in hardwood forest, $15 \%$ in grassland or pasture, $5 \%$ in mixed pine-hardwood forest, $5 \%$ in open water, $4 \%$ in agriculture, $3 \%$ in marsh, $2 \%$ in herbaceous, $2 \%$ in urban (1.2\% low-density and $0.06 \%$ high-density), and $<1 \%$ in each of the following: swamp, shrub, barren, and juniper forest. 


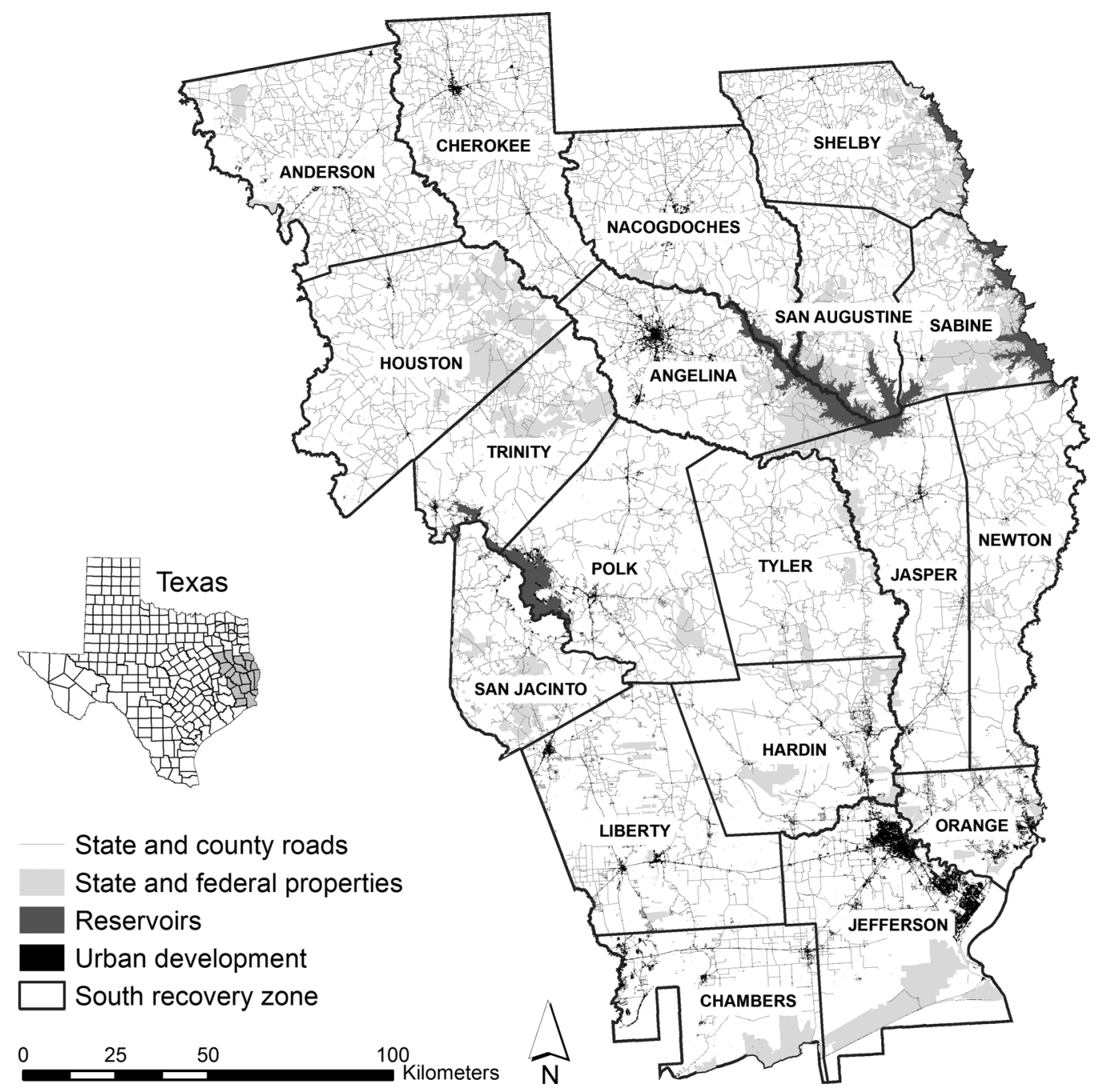

Figure 1. Area of eastern Texas designated as the south Louisiana black bear recovery zone and used as the boundary for modeling regional extent habitat suitability for the Louisiana black bear in 2009-2011.

\section{METHODS}

\section{East Texas Black Bear HSI Model}

Our HSI model was based on relationships between life requisite variables developed by van Manen (1991). The van Manen (1991) model quantified habitat suitability using measures of soft and hard mast production, understory vegetation density, tree den availability, and human-bear conflict zones. Typically, black bear HSI models include food, cover, and human impact components (Tankersley 1996, Bowman 1999, Mitchell et al. 2002, Larson et al. 2003, Hersey et al. 2005). Although some models have incorporated as many as 20 variables, Mitchell et al. (2002) suggested that simpler models consisting of food and denning variables better reflect population-level habitat selection by bears and Larson et al. (2003) suggested that resource availability is more important to modeling habitat quality for bears than abiotic components (e.g., slope and aspect). Our basic model thus included food $\left(\mathrm{CI}_{\mathrm{FOOD}}\right)$, cover $\left(\mathrm{CI}_{\mathrm{COVER}}\right)$, and human impact $\left(\mathrm{CI}_{\text {HUMAN IMPACT }}\right)$ component indices (CI) composed of 8 suitability index (SI) variables: summer food availability $\left(\mathrm{SI}_{\mathrm{SFA}}\right)$, fall food availability $\left(\mathrm{SI}_{\mathrm{FFA}}\right)$, fall food diversity $\left(\mathrm{SI}_{\mathrm{FFD}}\right)$, fall food productivity $\left(\mathrm{SI}_{\mathrm{FFP}}\right)$, protection cover $\left(\mathrm{SI}_{\mathrm{PC}}\right)$, tree den availability $\left(\mathrm{SI}_{\mathrm{TDA}}\right)$, distance to roads $\left(\mathrm{SI}_{\mathrm{R}}\right)$, and human development $\left(\mathrm{SI}_{\mathrm{HD}}\right.$; Table 1).

The van Manen (1991) model was designed to assign a mean HSI score based on empirical habitat data to distinct administrative boundaries capable of supporting minimum viable populations (MVPs) of black bears (i.e., a population with a $\geq 95 \%$ probability to survive for $\geq 100 \mathrm{yr}$ ). However, because habitat is generally heterogeneous over large landscapes, this approach of assigning a single suitability score masks underlying heterogeneity over large study areas. To apply the model at the region-level while maintaining small-scale detail, we calculated SI, CI, and HSI scores separately for each pixel in a continuous raster dataset based on empirical field-based habitat data.

We used the TVCP to identify potentially suitable habitat classes for black bears (i.e., classes identified through 
Table 1. Model equations for calculating suitability index (SI), component index (CI), and habitat suitability index (HSI) scores for evaluating the year-round habitat requirements of the Louisiana black bear in east Texas through field survey or geographic information system (GIS) data.

\begin{tabular}{|c|c|c|c|c|}
\hline Index & Habitat model & Survey method & Index equations & Literature cited \\
\hline $\mathrm{SI}_{\mathrm{SFA}}$ & Summer food availability & Field & $\begin{array}{l}x=\text { percent cover of all soft mast producing species } \\
\text { when } x<10, \mathrm{SI}_{\mathrm{SFA}}=0.1 x \\
\text { when } x \geq 10, \mathrm{SI}_{\mathrm{SFA}}=1.0\end{array}$ & van Manen (1991) \\
\hline $\mathrm{SI}_{\mathrm{FFA}}$ & Fall food availability & Field & $\begin{array}{l}x=\text { percent basal cover of all hard mast producing species } \\
\text { when } x \leq 15, \mathrm{SI}_{\mathrm{FFA}}=0.0 \\
\text { when } 15<x<40, \mathrm{SI}_{\mathrm{FFA}}=0.04 x-0.6 \\
\text { when } x \geq 40, \mathrm{SI}_{\mathrm{FFA}}=1.0\end{array}$ & van Manen (1991) \\
\hline $\mathrm{SI}_{\mathrm{FFD}}$ & Fall food diversity & Field & $\begin{array}{l}x=\text { number of hard mast groups existing in co-dominance } \\
\text { when } x=0, \mathrm{SI}_{\mathrm{FFD}}=0.0 \\
\text { when } x=1, \mathrm{SI}_{\mathrm{FFD}}=0.5 \\
\text { when } x \geq 2, \mathrm{SI}_{\mathrm{FFD}}=1.0\end{array}$ & van Manen (1991) \\
\hline $\mathrm{SI}_{\mathrm{FFP}}$ & Fall food productivity & Field & $\begin{array}{l}x=\text { percent of hard mast producing trees } \geq 40.6 \mathrm{~cm} \mathrm{dbh} \\
\text { when } 0<x<40, \mathrm{SI}_{\mathrm{FFP}}=0.025 x \\
\text { when } 40 \leq x \leq 60, \mathrm{SI}_{\mathrm{FFP}}=1.0 \\
\text { when } x>60, \mathrm{SI}_{\mathrm{FFP}}=-0.05 x+4\end{array}$ & van Manen (1991) \\
\hline $\mathrm{SI}_{\mathrm{PC}}$ & Protection cover & Field & $\begin{array}{l}x=\text { percent density of understory } \\
\text { when } x \leq 20, \mathrm{SI}_{\mathrm{PC}}=0 \\
\text { when } 20<x<80, \mathrm{SI}_{\mathrm{PC}}=-0.007 x+\left(2.38 \times 10^{-4}\right) x^{2}+0.06 \\
\text { when } x \geq 80, \mathrm{SI}_{\mathrm{PC}}=1.0\end{array}$ & Mitchell et al. (2002) \\
\hline $\mathrm{SI}_{\mathrm{TDA}}$ & Tree den availability & Field & $\begin{array}{l}x=\text { percent of trees } \geq 84.0 \mathrm{~cm} \mathrm{dbh} \\
\text { when } 0<x<5, \mathrm{SI}_{\mathrm{TDA}}=0.2 x \\
\text { when } 5 \leq x \leq 10, \mathrm{SI}_{\mathrm{TDA}}=1.0 \\
\text { when } x>10, \mathrm{SI}_{\mathrm{TDA}}=-0.0056 x+1.056\end{array}$ & van Manen (1991) \\
\hline $\mathrm{SI}_{\mathrm{R}}$ & Distance to roads & GIS & $\begin{array}{l}x=\text { distance to road }(\mathrm{km}) \\
\text { when } x=0, \mathrm{SI}_{\mathrm{R}}=0 \\
\text { when } 0<x<0.8, \mathrm{SI}_{\mathrm{R}}=0.156 x+0.195 x^{2} \\
\text { when } 0.8 \leq x<1.6, \mathrm{SI}_{\mathrm{R}}=0.25 \\
\text { when } x>1.6 \mathrm{~km}, \mathrm{SI}_{\mathrm{R}}=1.0\end{array}$ & Mitchell et al. (2002) \\
\hline $\mathrm{SI}_{\mathrm{HD}}$ & Human development & GIS & $\begin{array}{l}\text { Within urban buffer zone, } \mathrm{SI}_{\mathrm{HD}}=0.0 \\
\text { Outside urban buffer zone, } \mathrm{SI}_{\mathrm{HD}}=1.0\end{array}$ & Bowman (1999) \\
\hline $\mathrm{CI}_{\mathrm{FOOD}}$ & Food component & GIS & $\mathrm{CI}_{\mathrm{FOOD}}=\left(\mathrm{SI}_{\mathrm{SFA}} \times\left(\left(\mathrm{SI}_{\mathrm{FFA}}+\mathrm{SI}_{\mathrm{FFD}}+\mathrm{SI}_{\mathrm{FFP}}\right) / 3\right)^{2}\right)^{1 / 3}$ & van Manen (1991) \\
\hline $\mathrm{CI}_{\text {COVER }}$ & Cover component & GIS & $\begin{array}{l}\text { When } \mathrm{SI}_{\mathrm{TDA}}>\mathrm{SI}_{\mathrm{PC}} ; \mathrm{CI}_{\mathrm{COVER}}=\left(\mathrm{SI}_{\mathrm{PC}}+\mathrm{SI}_{\mathrm{TDA}}\right) / 2 \\
\text { When } \mathrm{SI}_{\mathrm{TDA}} \leq \mathrm{SI}_{\mathrm{PC}} ; \mathrm{CI}_{\mathrm{COVER}}=\mathrm{SI}_{\mathrm{PC}}\end{array}$ & van Manen (1991) \\
\hline $\mathrm{CI}_{\text {HUMAN IMPACT }}$ & Human impact component & GIS & $\mathrm{CI}_{\mathrm{HUMAN} \text { IMPACT }}=\left(\mathrm{SI}_{\mathrm{R}}+\mathrm{SI}_{\mathrm{HD}}\right) / 2$ & van Manen (1991) \\
\hline HSI & Habitat suitability index & GIS & $\mathrm{HSI}=\left(\left(2 \times \mathrm{CI}_{\mathrm{FOOD}}\right)+\mathrm{CI}_{\text {COVER }}+\mathrm{CI}_{\text {HUMAN IMPACT }}\right) / 4$ & van Manen (1991) \\
\hline
\end{tabular}

interpretation of the TVCP as potentially capable of meeting the year-round habitat requirements of black bears) in the SRZ and to select sample sites for field survey. The availability of TVCP data allowed us to stratify habitat surveys by class at the regional level and calculate suitability scores per pixel throughout the SRZ. We developed field surveys at the mapping systems level (i.e., Pineywoods: dry pine forest or plantation) of the TVCP, which was the finest level of resolution and had a produced map accuracy of $75 \%$ (A. Treuer-Kuehn, Texas Parks and Wildlife Department, personal communication). Although map accuracy for the TVCP at the most general land-cover level (i.e., pine forest) was $85 \%$, we used the mapping systems level because of ecological differences in habitat composition among classes within general land-cover types (i.e., differences between young pine plantation 1-3 $\mathrm{m}$ tall and mature Pineywoods: dry pine forest or plantation). However, HSI models are relative, not absolute, measures of habitat suitability as multiple, independent life requisite variables contribute to the overall ability of a given habitat to support a specified abundance of a given species. A lower or higher SI score for a single variable caused by slight differences in habitat between the 2 TVCP levels would only slightly decrease or increase the overall HSI score (Hersey et al. 2005). We therefore considered the additional 10\% mapping accuracy negligible for developing HSI scores and considered the improved habitat resolution biologically more important for modeling overall habitat suitability for black bears at the regional level.

\section{Habitat Field Survey}

We surveyed TVCP habitat classes that were $>2,000$ ha in total extent throughout the SRZ and that we identified as potentially suitable black bear habitats through examination of the TVCP interpretive booklet (Ludeke et al. 2009). We identified 38 of 98 habitat classifications for field surveys, which accounted for $82 \%$ of the land area in the region. We did not survey most non-habitats (e.g., agriculture and urban classifications; $6 \%$ of the area in the region), habitats along the periphery of the SRZ located outside of the Pineywoods ecoregion ( $11 \%$ of the area), or potentially suitable classes that were minor components within the Pineywoods ecoregion ( $1 \%$ of the area). We determined number of survey points necessary for collecting reliable data $(N)$ from a classified map using the binomial probability theory $(N=$ $\left(Z^{2} \times p \times q\right) / E^{2}$, where $Z=2$ from the standard normal deviate of 1.96 for the 2 -sided $95 \%$ confidence interval, $p$ is the expected percent map accuracy, $q=100-p$, and $E$ is the allowable error; Fitzpatrick-Lins 1981). Using the TVCP 
mapping system accuracy level of $75 \%$ for $p$ and an allowable error of $5 \%$, we calculated a minimum $N$ of 300 survey points. We stratified random points among the 38 selected habitat classes in ERDAS IMAGINE 9.3 (Intergraph Corporation, Madison, AL) and eliminated those that did not fall within a $3 \times 3$ neighborhood in which all 9 pixels were composed of the target class.

In addition to calculating the necessary sample size for assessing the overall accuracy of a classified map, we determined the necessary sample size $(n)$ for adequately sampling each surveyed habitat class. We used a formula based on the Student's $t$-test with a probability of $\alpha$ of committing a type I error and the probability of $\beta$ of committing a type II error (Zar 2010). We calculated variance $\left[s^{2}=\Sigma\left(x^{2}\right)-\left(\left(\Sigma(x)^{2}\right) / n\right)\right]$, minimum detectable difference $\left[\delta=\left(s^{2} / n\right) \times\left(t_{\alpha(2), v}+t_{\beta(1), v}\right)\right]$, and degrees of freedom $(v=n-1)$ for food and cover indices for each surveyed habitat class from our data. Using a confidence level of $0.95(=1-\alpha ; \alpha=0.05)$ and power of $0.90(=1-\beta$; $\beta=0.10$ ), we calculated $n$ according to the following equation: $n=\left(s^{2} / \delta^{2}\right) \times\left(t_{\alpha(2), v}+t_{\beta(1), v}\right)^{2}$.

We evaluated $\mathrm{SI}_{\mathrm{SFA}}, \mathrm{SI}_{\mathrm{FFA}}, \mathrm{SI}_{\mathrm{FFD}}, \mathrm{SI}_{\mathrm{FFP}}, \mathrm{SI}_{\mathrm{PC}}$, and $\mathrm{SI} \mathrm{TDA}$ according to van Manen (1991) and Siegmund (Stephen F. Austin State University, unpublished data). We established 1 0.04-ha fixed-radius plot and $45-\mathrm{m}^{2}$ relevé plots at each survey point. We divided each survey point into 4 quarters and located one relevé plot in each quarter with the closest corner of the relevé plot located at the closest tree to point center in that quarter.

For estimating $\mathrm{SI}_{\mathrm{SFA}}$, we recorded the species of all soft mast producing woody plants within each relevé plot and estimated percent cover of each in 5\% increments. We averaged data from the 4 relevé plots for each survey point. For estimating $\mathrm{SI}_{\mathrm{FFA}}, \mathrm{SI}_{\mathrm{FFD}}, \mathrm{SI}_{\mathrm{FFP}}$, and $\mathrm{SI}_{\mathrm{TDA}}$, we recorded the species and diameter at breast height (dbh) of all trees $\geq 15 \mathrm{~cm}$ dbh within the 0.04-ha plot.

For estimating $\mathrm{SI}_{\mathrm{PC}}$, we measured understory vegetation density using a vegetation profile board (Nudds 1977). We constructed a $30 \times 200-\mathrm{cm}$ profile board that incorporated a collapsible aluminum frame and a canvas sheet consisting of alternating $15 \times 25-\mathrm{cm}$ white and orange rectangle sections. We placed the profile board $15 \mathrm{~m}$ from point center in each quarter, in line with the closest tree to point center to minimize bias associated with subjective placement. We recorded vegetation density by code in $20 \%$ increments $(1=0-20 \%, 2=21-40 \%, 3=41-60 \%, 4=61-80 \%$, and $5=81-100 \%$; Nudds 1977, Griffith and Youtie 1988). We recorded density codes for every $30 \times 50-\mathrm{cm}$ section up to $200 \mathrm{~cm}$ above the ground. We averaged data from the 4 profile board readings per height section for each survey point. We only analyzed density readings for sections up to $100 \mathrm{~cm}$ based on the typical maximum shoulder height of black bears (van Manen 1991).

We measured hard and soft mast production, understory vegetation density, and tree den availability at 516 survey points in 2010 and 2011 (Fig. 2). Because of variability among survey points within classes, we exceeded our minimum $N$ of 300 samples for evaluating a classified map to meet sample size requirements for surveying individual habitat classes. Survey points were primarily located in 4 areas totaling $3,085 \mathrm{~km}^{2}$ : the Sabine and Angelina National Forests $\left(1,598 \mathrm{~km}^{2}\right)$, the Big Thicket National Preserve $\left(444 \mathrm{~km}^{2}\right)$, Tony Houseman Wildlife Management Area $\left(16 \mathrm{~km}^{2}\right)$, Masterson State Forest $\left(2 \mathrm{~km}^{2}\right)$, and private timber company properties $\left(1,025 \mathrm{~km}^{2}\right)$. We evaluated habitat in 38 of 98 habitat classes present in the SRZ, which accounted for $82 \%$ of the land area in the region. The number of survey points per habitat class ranged from 3 to $22(\bar{x}=13.6)$. We measured 158 survey points in hardwood, 110 in pine, 98 in mixed pine-hardwood, 50 in swamp, 40 in herbaceous, 36 in shrub, and 24 in non-habitat land-cover types (open water, pasture, and barren). We calculated necessary sample sizes for collecting reliable data from each surveyed habitat class and cover type based on food and cover component data. Using empirical data to calculate variance and minimum detectable difference, our sample populations were greater than or equal to the required sample size for all classes and types, suggesting they were adequately sampled (Kaminski 2011).

\section{HSI Model Development}

Using empirical overstory, understory, and vegetation density data, we calculated $\mathrm{SI}_{\mathrm{SFA}}, \mathrm{SI}_{\mathrm{FFA}}, \mathrm{SI}_{\mathrm{FFD}}, \mathrm{SI} \mathrm{IFP}_{\mathrm{FP}}$, $\mathrm{SI}_{\mathrm{PC}}, \mathrm{SI}_{\mathrm{TDA}}, \mathrm{CI}_{\mathrm{FOOD}}$, and $\mathrm{CI}_{\mathrm{COVER}}$ for each survey point. We calculated mean SI and CI scores per variable among survey points for each sampled habitat class and assigned scores to the TVCP attribute table in ArcGIS 9.3 (ESRI, Redlands, CA). To develop suitability scores for un-surveyed habitat classes ( $18 \%$ of the SRZ), we pooled data by landcover type (i.e., hardwood, pine, mixed pine-hardwood, herbaceous, shrub, and swamp) and developed mean SI and CI scores for each type. Although un-surveyed classes were primarily located along the periphery of the SRZ or were minor components across the landscape, we estimated scores for these classes in an effort to evaluate the suitability of habitats throughout the entire SRZ and because arbitrarily assigning scores equal to zero would likely underestimate the potential for these classes to meet 1 or multiple habitat requirements for black bears. We assigned pooled SI and CI type scores to un-surveyed habitat classes and developed raster-formatted models for $\mathrm{SI}_{\mathrm{SFA}}, \mathrm{SI}_{\mathrm{FFA}}, \mathrm{SI}_{\mathrm{FFD}}, \mathrm{SI}_{\mathrm{FFP}}$, $\mathrm{SI}$ PC, $\mathrm{SI}_{\mathrm{TDA}}, \mathrm{CI}_{\mathrm{FOOD}}$, and $\mathrm{CI}_{\mathrm{COVER}}$ using the Lookup tool in ArcGIS 9.3 to preserve cell size and alignment with the TVCP.

van Manen (1991) used open road density and human-bear conflict zone indices in which the linear distance of roads and the percent cover of human-impact zones were calculated for distinct administrative boundaries, respectively. Because our model was designed for application to a significantly larger area than these variables were designed to assess, we used the distance to roads variable $\left(\mathrm{SI}_{\mathrm{R}}\right)$ developed by Mitchell et al. (2002) and the human development variable $\left(\mathrm{SI}_{\mathrm{HD}}\right)$ described by Bowman (1999). The mathematical formulas associated with these variables allowed us to calculate distinct suitability scores per pixel for human-impact variables independent of the extent of our study area. 


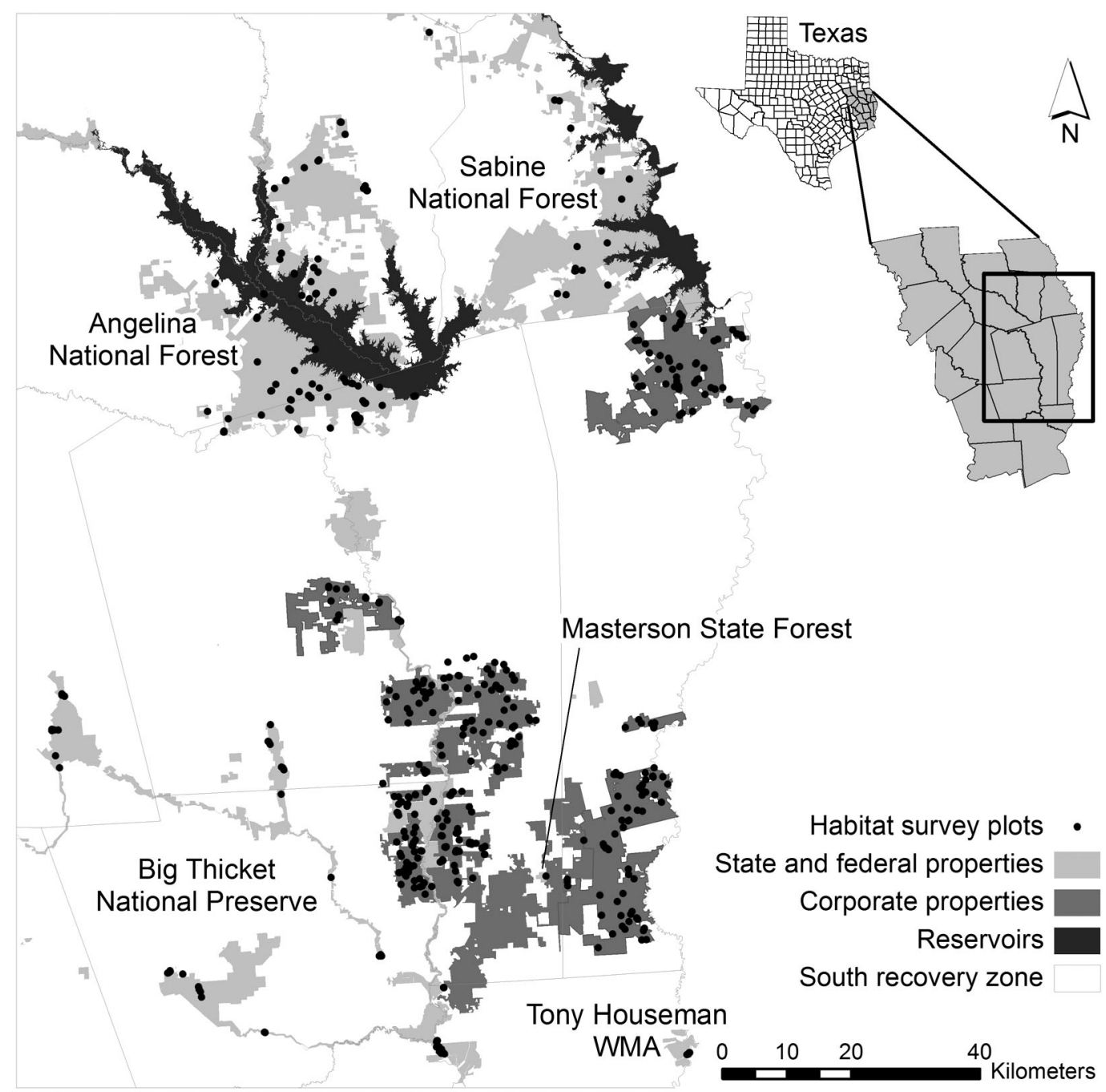

Figure 2. Primary study areas and fixed-radius plot locations for conducting field assessments of Louisiana black bear habitat suitability in $2009-2011$ in southeast Texas, USA.

Mitchell et al. (2002) developed the distance to roads variable assuming bears avoid areas within $1,600 \mathrm{~m}$ of roads. Although data regarding the effects of roads on habitat quality for black bears are conflicting (Carr and Pelton 1984, Hellgren et al. 1991, Clark et al. 1993, Fecske et al. 2002, Reynolds-Hogland and Mitchell 2007), we followed van Manen (1991) and assumed that roads have an overall negative effect through increased traffic-related mortality and increased efficiency for legal and illegal killing. Reynolds-Hogland and Mitchell (2007) found that black bears avoided areas $\leq 1,600 \mathrm{~m}$ from gravel roads when establishing home ranges and males and females avoided areas $\leq 800 \mathrm{~m}$ from roads during the summer and fall, respectively. Reynolds-Hogland and Mitchell (2007) concluded that roads affect habitat quality at a relatively large spatial scale. We thus buffered all state and county roads in $10-\mathrm{m}$ increments out to $800 \mathrm{~m}$ and from $800 \mathrm{~m}$ to $1,600 \mathrm{~m}$ using a single buffer in ArcGIS 9.3. We calculated SI scores for buffer rings according to Mitchell et al. (2002) and converted the model to a raster format with cell size and alignment consistent with the TVCP.

Bowman (1999) used a human development variable that incorporated buffers based on female home range size around low- and high-density urban development. Since the TVCP model included low- and high-density urban classes, we developed buffers according to Bowman (1999). van Manen (1991) conceptualized a home range as a circle with the diameter representing the greatest distance an individual bear will travel to meet its year-round habitat requirements. Using this circular home range concept, we estimated a mean female Louisiana black bear home range as a circle with a diameter of $3.9 \mathrm{~km}$ based on home range estimates for an established population of Louisiana black bears in Louisiana $\left(\bar{x}=12 \mathrm{~km}^{2}\right.$; Benson and Chamberlain 2007). We created buffers of $3.9 \mathrm{~km}$ and $1.1 \mathrm{~km}$ around all high- and low-density urban development, respectively, and calculated SI scores according to Bowman (1999). Because the TVCP high-density urban component incorporated road 
development, we clipped the high-density urban component with incorporated urban polygon data maintained in the Texas Natural Resource Information System (Texas Water Development Board, Austin, TX) to eliminate redundancy of roads data in our model.

\section{Identification of Recovery Units}

van Manen (1991) estimated an MVP of black bears to be 50-90 individuals based on 1) estimates developed for grizzly bears (U. arctos) by Shaffer (1983) and 2) the estimated minimum population size necessary to prevent negative genetic effects related to inbreeding within an MVP for 100 years (Franklin 1980, Soulé 1980). Based on density estimates for a black bear population near carrying capacity $\left(\bar{x}=1\right.$ bear per $\left.2.3 \mathrm{~km}^{2}\right)$, van Manen (1991) estimated that 11,500 ha to 20,700 ha of suitable bear habitat were necessary for maintaining a MVP. van Manen (1991) further reported HSI scores of $0.49-0.56$ for 3 study units containing established black bear populations in the southern Appalachians. Using values presented by van Manen (1991), we defined suitable habitat as pixels with HSI scores $\geq 0.50$ (Garner and Willis 1998). To assess areas capable of supporting an MVP of black bears in the SRZ (i.e., recovery units), we used a neighborhood analysis of our final HSI model in ArcGIS 9.3 (Osborne et al. 2001, McComb et al. 2002, Gibson et al. 2004). We used a circular moving window to reassign the mean value of pixels within an area the size of 1 female Louisiana black bear home range (1,950$m$ radius according to our circular home range estimates) to the central focal pixel. We exported pixels with mean HSI scores $\geq 0.5$ and created buffers around pixels of $1,950 \mathrm{~m}$ to identify areas within our final HSI where the mean score was equal to 0.5 (i.e., the area used within each moving window analysis). We considered recovery units as areas $\geq 20,700 \mathrm{ha}$ with a mean HSI score equal to 0.5 as a conservative estimate for the minimum area necessary to support a viable bear population according to van Manen (1991).

\section{RESULTS}

We developed our final HSI model at $10-\mathrm{m}$ resolution and it encompassed the SRZ (Fig. 3). HSI scores in the region ranged from 0.00 to 0.76 . We considered scores $\geq 0.75$ as highly suitable, $0.50-0.74$ as moderately suitable, and $<0.50$ as marginal or unsuitable (van Manen 1991, Garner and Willis 1998). Our model indicated that highly $(<1 \%)$ and moderately (16\%) suitable habitat existed throughout the SRZ, although most of the area (84\%) was classified as marginal or unsuitable habitat.

We identified 4 recovery units potentially capable of supporting minimum viable black bear populations in the SRZ. The Middle Neches River Recovery Unit (MNRRU) was located in the Middle Neches River Basin and was comprised of 6 polygons of suitable habitat $(3,927$ ha to $35,565 \mathrm{ha}, \bar{x}=22,360 \mathrm{ha}$ ) totaling $67,076 \mathrm{ha}$. The mean HSI score for the area was 0.5 and 30,712 ha of the recovery unit was comprised of pixels scoring $0.5 \leq \mathrm{HSI} \leq 0.76(\bar{x}=0.58)$. Land ownership consisted of state (1,398 ha), federal $(4,721 \mathrm{ha})$, and private $(60,957 \mathrm{ha})$ properties. The Lower
Neches River Recovery Unit (LNRRU) was located in the Lower Neches River Basin and was comprised of 5 polygons of suitable habitat $(5,550 \mathrm{ha}$ to $35,889 \mathrm{ha}, \bar{x}=15,156 \mathrm{ha})$ totaling 75,777 ha. The mean HSI score for the area was 0.5 and 41,781 ha of the recovery unit was comprised of pixels scoring $0.5 \leq \mathrm{HSI} \leq 0.76(\bar{x}=0.59)$. Land ownership consisted of state $(5,336 \mathrm{ha})$, federal $(8,415 \mathrm{ha})$, and private (62,026 ha) properties. The Sabine River Recovery Unit (SRRU) was located in the Sabine River Basin and was comprised of 9 polygons of suitable habitat (1,396 ha to $19,519 \mathrm{ha}, \bar{x}=6,360 \mathrm{ha}$ ) totaling $62,844 \mathrm{ha}$. The mean HSI score for the area was 0.5 and 31,876 ha of the recovery unit was comprised of pixels scoring $0.5 \leq \mathrm{HSI} \leq 0.76(\bar{x}=0.58)$. Land ownership consisted entirely of private properties. The Lower Trinity River Recovery Unit (LTRRU) was located in the Lower Trinity River Basin and was comprised of 4 polygons of suitable habitat $(4,559$ ha to 88,750 ha, $\bar{x}$ $=31,203 \mathrm{ha}$ ) totaling $124,808 \mathrm{ha}$. The mean HSI score for the area was 0.5 and 65,490 ha of the recovery unit was comprised of pixels scoring $0.5 \leq \mathrm{HSI} \leq 0.75(\bar{x}=0.60)$. Land ownership consisted of state (487 ha), federal $(12,453 \mathrm{ha})$, and private $(111,868 \mathrm{ha})$ properties.

\section{DISCUSSION}

Our regional extent model successfully allowed us to identify areas of southeastern Texas with the greatest potential to support Louisiana black bear populations and potentially other bottomland hardwood-associated wildlife going into the future. Large recovery units with a mean HSI score of 0.5 existed that were 3-6 times larger than the estimated minimum area necessary for establishing an MVP of black bears in the SRZ. Within each recovery unit, areas of suitable habitat (pixels scoring $\geq 0.5$ in $\mathrm{HSI}$ ) existed that also exceeded the minimum 20,700 ha necessary for establishing an MVP of black bears. The mean HSI scores estimated for suitable habitat pixels within our recovery units $(0.58,0.58$, 0.59 , and 0.60 ) were comparable to those developed by van Manen (1991; 0.49, 0.55, 0.56, 0.63, and 0.71) for occupied areas of the southern Appalachians. Our scores equated to moderately suitable habitat, which van Manen (1991) showed was adequate for maintaining sustainable black bear populations. Our scores were similarly comparable to those developed by Siegmund (unpublished data) for areas of the Sulphur, Cypress, and Red River Basins in northeast Texas $(0.55,0.66$, and 0.74, respectively). However, Garner and Willis (1998) developed scores of 0.73, 0.79, and 0.89 for portions of the Big Thicket National Preserve, Lower Neches River Basin, and Middle Neches River Basin in the SRZ, respectively. The scores estimated for the Lower and Middle Neches River Basins equate to highly suitable habitat and were considerably higher than those developed in our study. The differences between our scores and those estimated by Garner and Willis (1998) for the Lower and Middle Neches River Basins are probably related to 2 factors. First, data collected by Garner and Willis (1998) were collected 18 years prior to our study. Habitat in these river basins has likely changed dramatically considering the increased rate of hardwood timber harvests and increased 


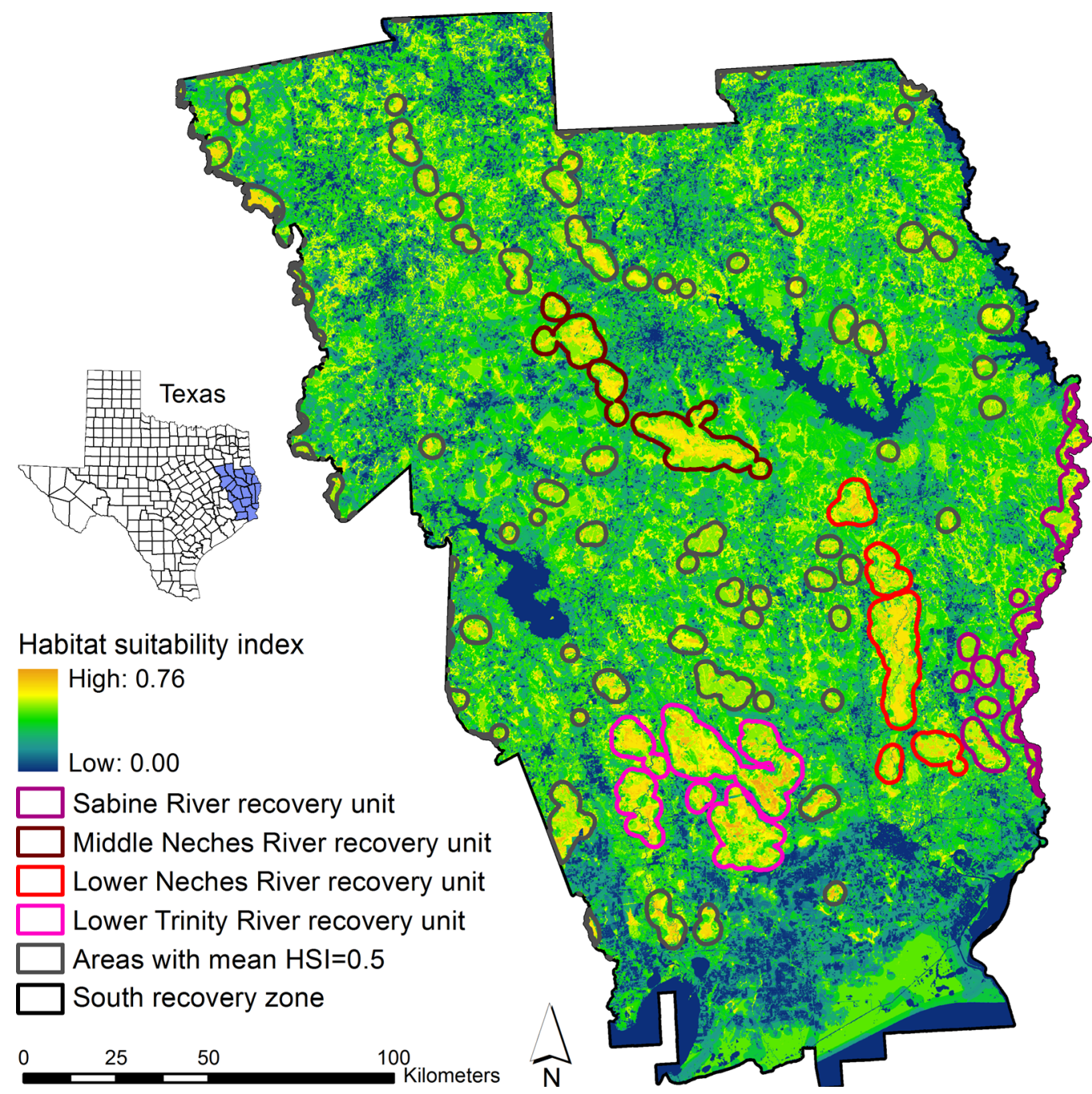

Figure 3. Final habitat suitability index model developed for the south Louisiana black bear recovery zone and potential recovery units capable of sustaining viable black bear populations in 2009-2011 in southeast Texas, USA. We identified recovery units with a mean habitat suitability index (HSI) score equaling 0.5 using a moving window analysis (1,950-m radius). Additional areas were identified (gray polygons) although not included as part of recovery units because they 1) did not meet the minimum area requirements for sustaining viable populations, 2) were greater than 1 female Louisiana black bear home range distance from identified recovery units, or 3) were geographically separated from recovery units by human development.

value of hardwood sawlogs and pulpwood in the region (Kelly et al. 1992, Miller and Hartsell 1992, Bentley and Johnson 2004, Texas Forest Service 2011). Second, our study area was geographically larger and did not focus on areas solely in and around the Neches River Basin and Big Thicket National Preserve, which consisted of higher suitability bottomland hardwood habitats. Garner and Willis (1998) selected study areas based on the presence of perceived highly suitable habitats and likely generated higher overall mean HSI scores when compared with ours. Although increased sampling in higher suitability habitats should lend more precise SI estimates in those classes, Garner and Willis (1998) did not stratify sampling by habitat class and estimated mean HSI scores independent of class. Unless habitat surveys are stratified per class or data weighted according to the total area each class comprises within a study area, over sampling in higher suitability habitats will likely result in artificially higher mean HSI scores. Furthermore, our GIS-based approach for identifying recovery units likely resulted in the inclusion of larger proportions of habitat on the lower end of the moderately suitable category (i.e., $0.5<\mathrm{HSI}<0.6)$ because we used HSI scores to delineate recovery units independent of our field study area. For our study, we had access to detailed, high-resolution land-cover information that did not exist during previous HSI studies in east Texas. We assigned HSI scores to individual pixels based on habitat classes. Because we calculated mean recovery unit scores from pixels, mean scores were reflective of the proportion of each habitat class comprising each recovery unit. Essentially, this method was analogous to a stratified sampling methodology by habitat class because each habitat class was weighted according to the amount of area it comprised in each recovery unit.

The Tensas River Basin (TRB) subpopulation of Louisiana black bears exists within a 29,000-ha tract of bottomland hardwood forest along the Tensas River Basin, Louisiana 
(Benson and Chamberlain 2007). Bowman (1999) estimated habitat suitability for the TRB to be $0.74(99.2 \% \mathrm{CI}=$ 0.56-0.92) using the van Manen (1991) HSI. Recent reports estimated this population at 294 bears (Hooker 2010). Considering the high population density of the TRB subpopulation, relatively similar or smaller geographic size of the TRB compared with our recovery units, and relatively similar habitat of the TRB compared with our recovery units (e.g., bottomland hardwood forest; Benson and Chamberlain 2007), we expect that our recovery units are more than adequate for establishing sustainable populations of black bears in east Texas. Notably, high rates of agricultural food use by bears in the TRB were documented and probably contributed to the high density of the population (Benson and Chamberlain 2006). Agriculture comprised approximately $4 \%$ of the land cover in the SRZ and likely will not contribute greatly to the year-round nutrition of black bears in the region. This is ultimately advantageous because agricultural food use is likely to negatively affect populations through increased negative human-bear interactions (van Manen 1991). However, potential population densities and abundance in the SRZ may be lower than those documented in the TRB as a result.

Our recovery units consisted of multiple suitable habitat polygons (mean $\mathrm{HSI}=0.5$ ) connected by patches of contiguous forest typically no further apart than the mean female Louisiana black bear home range size (van Manen 1991). The diameter of the mean female Louisiana black bear home range is a conservative estimate for the maximum travel distance of black bears because most black bear populations in the southeastern United States have considerably larger home range sizes (up to $55 \mathrm{~km}^{2}$ ) than those documented in the TRB (Garshelis and Pelton 1981, Hellgren and Vaughan 1987, Maehr et al. 2003, Dobey et al. 2005, Moyer et al. 2007). We selected polygons connected by contiguous forested habitat to ensure that appropriate habitat linkages existed among polygons comprising recovery units (Kindall and van Manen 2007). Although connecting habitats did not meet the year-round habitat requirements of black bears, they typically met the requirements for summer food availability and protection cover. Seasonal shifts in home range are common among black bears as they exploit seasonally available food sources (Beeman and Pelton 1980, Graber and White 1983, Garner and Vaughan 1988, Hellgren and Vaughan 1988) and dense protection cover is essential for hibernating bears in the absence of suitable tree dens (Weaver and Pelton 1994, Oli et al. 1997). Thus, these areas may provide seasonal resources for black bear populations in addition to those found within our delineated recovery units.

Compared to assessments of habitat suitability in the region based entirely on remotely sensed data (Kaminski 2011, Morzillo et al. 2011), our analysis resulted in a considerably smaller proportion of the area being classified as suitable habitat ( $17 \%$ vs. $32 \%$ and $73 \%$, respectively). Although suitability modeling based entirely on remotely sensed data may provide useful information when agency resources limit empirical survey effort (Clevenger et al. 2002), conclusions should be regarded with caution and verified using independent data (Mitchell et al. 2002). For instance, Morzillo et al. (2011) concluded that federal lands were capable of supporting viable bear populations in east Texas. Based on our field results, federal lands in east Texas generally produced marginal suitability scores because pine plantations were the predominant land-cover type and lacked necessary resources to support viable bear populations. In general, suitability scores assigned a priori to generalized habitat classes (i.e., pine or hardwood) differed from scores based on field assessments of the TVCP habitat classes by $16 \%$ to $47 \%$, with consistent overestimation of suitability for hardwood types in particular (Kaminski 2011). These results emphasize the utility of using field data to verify assumptions about habitat suitability from remotely sensed data.

The strength of our modeling approach was that we selected model variables that were reflective of known black bear habitat use and could be evaluated across a broad geographic region independent of an established population. Geospatial modeling is limited by the availability of GIS datasets applicable to a given species' ecological requirements (Gibson et al. 2004). However, the datasets that we incorporated may be obtained through habitat survey and modeling of common urban spatial data. Gibson et al. (2004) noted the rarity of studies in the literature that combined geospatial modeling with field-based habitat assessment and recommended that this approach would likely be an advantageous, yet costly, modeling method for fine-scale habitat assessment. In the case of our study, we were assisted by the availability of the high-quality and fine-resolution TVCP spatial dataset. However, as Gibson et al. (2004) suggested, we were required to invest 2 field seasons to generate statistically adequate sample sizes for our habitat surveys. Ultimately, the additional cost resulted in the development of a fine-resolution HSI model capable of identifying priority areas at the regional level. For Texas or other states with detailed digital land-cover databases, this approach could be used to develop regional extent suitability models for any species for which habitat requirements are well understood.

The absence of an established black bear population in east Texas meant our HSI model lacked model validation for developing a level of precision according to Mitchell et al. (2002). Mitchell et al. (2002) considered an HSI model a hypothesis and model validation to be an evaluation of the model with independent home range or telemetry data. We derived our model assumptions from long-term monitoring of established black bear populations and well-documented black bear habitat requirements. van Manen (1991) evaluated HSI scores with home range data and showed that the HSI was reflective of habitat use in the southern Appalachians. Additionally, we developed our SI, CI, and HSI scores from empirical habitat data and evaluated them using standard sampling statistics. Although we derived our HSI scores from empirical habitat data, scores do not reflect actual black bear use in east Texas. However, Mitchell and Powell (2003) noted that bias associated with black bear HSI models was likely minimal because 1) a large number of component- 
based HSI models exist that approximate the relationship between black bears and their habitat, 2) HSI estimates are not exceedingly sensitive to any 1 component, and 3 ) the use of multiple, relatively independent component indices limits directional bias in applications of the full HSI. Thus, we regard the combination of using previously validated HSI models and statistically validated habitat survey to be suitable for identifying potential recovery units in areas lacking an established black bear population or site-specific use data.

\section{MANAGEMENT IMPLICATIONS}

Our results indicate that areas of large, contiguous forested habitat capable of meeting the year-round habitat requirements of Louisiana black bears and sustaining viable populations exist within the historical range of the subspecies in east Texas. The identification of recovery units based on the ecological requirements of black bears provides areas in which future management, research, public outreach, or reintroduction efforts may be targeted. The recovery units we presented are each comprised of $>80 \%$ private landownership, which emphasizes the need to incorporate public outreach and education with management actions, and to develop incentive programs for private landowners to conserve high-quality habitats for the long-term. Collaboration with private landowners to implement uneven-aged and/or longer rotation forest management could boost fall food variables in critical bottomland hardwood habitats and improve overall HSI estimates. However, because forest management practices and recovery-unit HSI estimates in east Texas are similar to those in areas with established black bear populations in the southeastern United States, we suggest that habitat fragmentation and the conversion of forestlands to less renewable resources poses a greater risk to the sustainability of recovery units. Thus management actions should focus on preserving large contiguous forested habitats free of human disturbance in and around recovery units.

\section{ACKNOWLEDGMENTS}

Primary funding for this project was provided by the Texas Parks and Wildlife Department, with additional significant contributions from the Black Bear Conservation Coalition, the Coypu Foundation, and the East Texas Black Bear Task Force. D. Kaminski received funding from the Arthur Temple College of Forestry and Agriculture, Stephen F. Austin State University, and from the USDA McIntireStennis Program. We thank D. Scognamillo and D. Unger for providing GIS support and review of our HSI model, S. Lange for providing spatial data, and J. Williams for providing technical support throughout the duration of this study. We thank D. Coble and W. Conway for providing assistance with statistics and study design. Land access for this study was provided by the U.S. Forest Service (J. Engle and E. Taylor), Big Thicket National Preserve (D. Roemer and B. Lockwood), Campbell Timberland Management LLC (B. Stansfield, D. Dietz, and M. Richardson), and Hancock Forest Management (C. Nichol). Campbell Timberland Management LLC also provided housing for our field technicians. We thank S. Payne for assisting with field data collection. We also thank our referees for providing comments that improved our manuscript.

\section{LITERATURE CITED}

Allen, A. W. 1983. Habitat suitability index models: beaver. U.S. Fish and Wildlife Service FWS/OBS-82/10.30 Revised, Washington, D.C., USA.

Beeman, L. E., and M. R. Pelton. 1980. Seasonal foods and feeding ecology of black bears in the Smoky Mountains. Proceedings of the International Conference on Bear Research and Management 4:141-147.

Benson, J. F., and M. J. Chamberlain. 2006. Food habits of Louisiana black bears (Ursus americanus luteolus) in two subpopulations of the Tensas River Basin. American Midland Naturalist 156:188-197.

Benson, J. F., and M. J. Chamberlain. 2007. Space use and habitat selection by female Louisiana black bears in the Tensas River Basin of Louisiana. Journal of Wildlife Management 71:117-126.

Bentley, J. W., and T. G. Johnson. 2004. Eastern Texas harvest and utilization study, 2003. U.S. Forest Service Resource Bulletin SRS-97, Southern Research Station, Asheville, North Carolina, USA.

Bowman, J. L. 1999. An assessment of habitat suitability and human attitudes for black bear restoration in Mississippi. Dissertation, Mississippi State University, Starkville, USA.

Brooks, B. L., and S. A. Temple. 1990. Habitat availability and suitability for loggerhead shrikes in the upper Midwest. American Midland Naturalist 123:75-83.

Carr, P. C., and M. R. Pelton. 1984. Proximity of adult female black bears to limited access roads. Proceedings of the Southeastern Association of Fish and Wildlife Agencies 38:70-77.

Clark, J. D., J. E. Dunn, and K. G. Smith. 1993. A multivariate model of female black bear habitat use for a geographic information system. Journal of Wildlife Management 57:519-526.

Clevenger, A. P., J. Wierzchowski, B. Chruszcz, and K. Gunson. 2002. GIS-generated, expert-based models for identifying wildlife habitat linkages and planning mitigation passages. Conservation Biology 16: 503-514.

Cook, J. G., and L. L. Irwin. 1985. Validation and modification of a habitat suitability model for pronghorns. Wildlife Society Bulletin 13:440-448.

Danks, F. S., and D. R. Klein. 2002. Using GIS to predict potential wildlife habitat: a case study of muskoxen in northern Alaska. International Journal of Remote Sensing 23:4611-4632.

Didier, K. A., and W. F. Porter. 1999. Large-scale assessment of potential habitat to restore elk to New York State. Wildlife Society Bulletin 27: 409-418.

Dobey, S., D. V. Masters, B. K. Scheick, J. D. Clark, M. R. Pelton, and M. E. Sunquist. 2005. Ecology of Florida black bears in the OkefenokeeOsceola ecosystem. Wildlife Monographs 158:1-41.

Fecske, D. M., R. E. Barry, F. L. Precht, H. B. Quigley, S. L. Bittner, and T. W. Webster. 2002. Habitat use by female black bears in western Maryland. Southeastern Naturalist 1:77-92.

Felix, A. B., H. Campa, III, K. F. Millenbah, S. R. Winterstein, and W. E. Moritz. 2004. Development of landscape-scale habitat-potential models for forest wildlife planning and management. Wildlife Society Bulletin 32:795-806

Fitzpatrick-Lins, K. 1981. Comparison of sampling procedures and data analysis for land-use and land-cover map. Photogrammetric Engineering and Remote Sensing 47:343-351.

Franklin, I. R. 1980. Evolutionary change in small populations. Pages 135150 in M. E. Soule and B. A. Wilcox, editors. Conservation biology: an evolutionary-ecological perspective. Sinauer Associates, Sunderland, Massachusetts, USA.

Garner, N. P., and M. R. Vaughan. 1988. Black bears use of abandoned home sites in Shenandoah National Park. Proceedings of the International Conference on Bear Research and Management 7:151-157.

Garner, N. P., and S. E. Willis. 1998. Suitability of habitats in east Texas for black bears. Texas Parks and Wildlife Department, Tyler, USA.

Garshelis, D. L., and M. R. Pelton. 1981. Movements of black bears in the Great Smoky Mountains National Park. Journal of Wildlife Management 45:912-925

Gerrard, R., P. Stin, R. Church, and M. Gilpin. 2001. Habitat evaluation using GIS: a case study applied to the San Joaquin kit fox. Landscape and Urban Planning 52:239-255. 
Gibson, L. A., B. A. Wilson, D. M. Cahill, and J. Hill. 2004. Spatial prediction of rufous bristlebird habitat in a coastal heathland: a GIS-based approach. Journal of Applied Ecology 41:213-223.

Graber, D. M., and M. White. 1983. Black bear food habits in Yosemite National Park. Proceedings of the International Conference on Bear Research and Management 5:1-10.

Griffith, B., and B. A. Youtie. 1988. Two devices for estimating foliage density and deer hiding cover. Wildlife Society Bulletin 16:206-210.

Gurnell, J., M. J. Clark, P. W. W. Lurz, M. D. F. Shirley, and S. P. Rushton. 2002. Conserving red squirrels (Sciurus vulgaris): mapping and forecasting habitat suitability using a geographic information systems approach. Biological Conservation 105:53-64.

Hellgren, E. C., and M. R. Vaughan. 1987. Home range and movements of winter-active black bears in the Great Dismal Swamp. Proceedings of the International Conference on Bear Research and Management 7:227-234.

Hellgren, E. C., and M. R. Vaughan. 1988. Seasonal food habits of black bears in Great Dismal Swamp, Virginia-North Carolina. Proceedings of the Southeastern Association of Fish and Wildlife Agencies 42:295-305.

Hellgren, E. C., M. R. Vaughan, and D. F. Stauffer. 1991. Macrohabitat use by black bears in a southeastern wetland. Journal of Wildlife Management $55: 442-448$

Hersey, K. R., A. S. Edwards, and J. D. Clark. 2005. Assessing American black bear habitat in the Mobile-Tensaw Delta of southwestern Alabama. Ursus 16:245-254.

Hooker, M. J. 2010. Estimating population parameters of the Louisiana black bear in the Tensas River Basin, Louisiana, using robust design capture-mark-recapture. Thesis, University of Tennessee, Knoxville, USA.

Kaminski, D. J. 2011. Assessment of the population status and evaluation of suitable habitats for the Louisiana black bear (Ursus americanus luteolus) in east Texas. Thesis, Stephen F. Austin State University, Nacogdoches, Texas, USA.

Kelly, J. F., P. E. Miller, and A. J. Hartsell. 1992. Forest statistics for southeast Texas counties-1992. U.S. Forest Service Resource Bulletin SO-17, Southern Forest Experimental Station, New Orleans, Louisiana, USA.

Kindall, J. L., and F. T. van Manen. 2007. Identifying habitat linkages for American black bears in North Carolina, USA. Journal of Wildlife Management 71:487-495.

Laliberte, A. S., and W. J. Ripple. 2004. Range contractions of North American carnivores and ungulates. Bioscience 54:123-138.

Larson, M. A., W. D. Dijak, F. R. Thompson, III, and J. J. Millspaugh. 2003. Landscape-level habitat suitability models for twelve wildlife species in southern Missouri. U.S. Forest Service General Technical Report NC233. North Central Research Station, St. Paul, Minnesota, USA.

Linden, D. W., H. Campa, III, G. J. Roloff, D. E. Beyer, Jr., and K. F. Millenbah. 2011. Modeling habitat potential for Canada lynx in Michigan. Wildlife Society Bulletin 35:20-26.

Ludeke, K., D. German, and J. Scott. 2009. Texas vegetation classification project: interpretive booklet for phase II. Texas Parks and Wildlife Department and Texas Natural Resources Information System, Austin, USA.

Maehr, D. S., J. S. Smith, M. W. Cunningham, M. E. Barnwell, J. L. Larkin, and M. A. Orlando. 2003. Spatial characteristics of an isolated Florida black bear population. Southeastern Naturalist 2:433-446.

McComb, W. C., M. T. McGrath, T. A. Spies, and D. Vesely. 2002. Models for mapping potential habitat at landscape scales: an example using northern spotted owl. Forest Science 48:203-216.

Miller, P. E., and A. J. Hartsell. 1992. Forest statistics for east Texas counties-1992. U.S. Forest Service Resource Bulletin SO-17, Southern Forest Experiment Station, New Orleans, Louisiana, USA.

Mitchell, M. S., and R. A. Powell. 2003. Response of black bears to forest management in the southern Appalachian mountains. Journal of Wildlife Management 67:692-705.

Mitchell, M. S., J. W. Zimmerman, and R. A. Powell. 2002. Test of a habitat suitability index for black bears in the southern Appalachians. Wildlife Society Bulletin 30:794-808.

Morzillo, A. T., J. R. Ferrari, and J. Liu. 2011. An integration of habitat evaluation, individual based modeling, and graph theory for a potential black bear population recovery in southeastern Texas, USA. Landscape Ecology 26:69-81.

Moyer, M. A., J. W. McCown, and M. K. Oli. 2007. Factors influencing home-range size of female Florida black bears. Journal of Mammalogy 88:468-476.

National Oceanic and Atmospheric Administration. 2002a. Precipitation. Climatography of the United States No. 85. National Climatic Data Center/NESDIS/NOAA, Asheville, North Carolina, USA.

National Oceanic and Atmospheric Administration. 2002b. Temperature. Climatography of the United States No. 85. National Climatic Data Center/NESDIS/NOAA, Asheville, North Carolina, USA.

Nixon, E. S. 2000. Trees, shrubs, and woody vines of East Texas. Second edition. B.L. Cunningham Productions, Nacogdoches, Texas, USA.

Nudds, T. D. 1977. Quantifying the vegetative structure of wildlife cover. Wildlife Society Bulletin 5:113-117.

O’Brien, C. S., S. S. Rosenstock, J. J. Hervert, J. L. Bright, and S. R. Boe. 2005. Landscape-level models of potential habitat for Sonoran pronghorn. Wildlife Society Bulletin 33:24-34.

Oli, M. K., H. A. Jacobson, and B. D. Leopold. 1997. Denning ecology of black bears in the White River National Wildlife Refuge, Arkansas. Journal of Wildlife Management 61:700-706.

Osborne, P. E., J. C. Alonso, and R. G. Bryant. 2001. Modelling landscapescale habitat use using GIS and remote sensing: a case study with great bustards. Journal of Applied Ecology 38:458-471.

Reynolds-Hogland, M. J., and M. S. Mitchell. 2007. Effects of roads on habitat quality for bears in the southern Appalachians: a long-term study. Journal of Mammalogy 88:1050-1061.

Rubin, E. S., C. J. Stermer, W. M. Boyce, and S. G. Torres. 2009. Assessment of predictive habitat models for bighorn sheep in California's Peninsular ranges. Journal of Wildlife Management 73:859-869.

Shaffer, M. L. 1983. Determining minimum viable population sizes for the grizzly bear. International Conference on Bear Research and Management 5:133-139.

Soulé, M. E. 1980. Thresholds for survival: maintaining fitness and evolutionary potential. Pages 151-170 in M. E. Soulé and B. A. Wilcox, editors. Conservation biology: an evolutionary-ecological perspective. Sinauer Associates, Sunderland, Massachusetts, USA.

Tankersley, R. 1996. Black bear habitat in the southeastern United States: a biometric model of habitat conditions in the southern Appalachians. Thesis, University of Tennessee, Knoxville, USA.

Texas Forest Service. 2011. Texas Forest Service, Texas A\&M University System. Texas price trends: historical timber price summary from 1984. $<$ http://txforestservice.tamu.edu/main/article.aspx?id=148>. Accessed 15 Nov 2011.

Texas Parks and Wildlife Department. 2005a. East Texas black bear conservation and management plan. Texas Parks and Wildlife Department, Austin, USA.

Texas Parks and Wildlife Department. 2005b. Pineywoods ecoregion. Page 162-177 in S. Bender, S. Shelton, K. C. Bender, and A. Kalmbach, editors. Texas comprehensive wildlife conservation strategy. Texas Parks and Wildlife Department, Austin, USA.

U.S. Fish and Wildlife Service. 1980. Habitat evaluation procedures (HEP) 102 ESM. U.S. Fish and Wildlife Service, Washington, D.C., USA.

van Manen, F. T. 1991. A feasibility study for the potential reintroduction of black bears into the Big South Fork Area of Kentucky and Tennessee. Tennessee Wildlife Resources Agency Technical Report No. 91-3, Knoxville, USA.

van Manen, F. T., and M. R. Pelton. 1997. A GIS model to predict black bear habitat use. Journal of Forestry 95:6-12.

Weaver, K. M., and M. R. Pelton. 1994. Denning ecology of black bears in the Tensas River Basin of Louisiana. Proceedings of the International Conference on Bear Research and Management 9:427-433.

Wooding, J. B., J. A. Cox, and M. R. Pelton. 1996. Distribution of black bears in the southeastern coastal plain. Proceedings of the Southeastern Association of Fish and Wildlife Agencies 48:270-275.

Zar, J. H. 2010. Biostatistical analysis. Fifth edition. Prentice Hall, Upper Saddle River, New Jersey, USA.

Associate Editor: Michael Chamberlain. 